\title{
Creating Relationships with the Self and Others by Choosing a Healthy Lifestyle
}

\author{
Saulius Vaivada ${ }^{1}$ Vilma Žydžiūnaitè ${ }^{2}$
}

1 Šiauliai University, Institute of Education, P. Višinskio g. 38, LT-76352 Šiauliai, Lithuania, vaivadas@gmail.com Public Health Improvement Division of Public Health Bureau of Šiauliai City Municipality, Varpo g. 9, LT-76346 Šiauliai, Lithuania, saulius.vaivada@sveikatos-biuras.lt

2 Vytautas Magnus University, Academy of Education, Institute of Educational Research, Jonavos g. 66, LT-44191 Kaunas, Lithuania, vilma.zydziunaite@vdu.lt

Klaipeda State University of Applied Sciences, Department of Nursing and Social Welfare, Faculty of Health Sciences, K. Donelaičio g. 10, LT-92143 Klaipeda, Lithuania, v.zydziunaite@ilk.lt

\begin{abstract}
The article answers the research question „What kind of multi-component content emerges when the person is creating a constructive relationship with the self and others when s/he chooses a healthy lifestyle?" through qualitative empirical study. Findings led to the conclusion that results of the creation of a personal relationship by choosing a healthy lifestyle are the transformations of the personality and quality of life, which are conditioned by personal change in the person's becoming and the promotion of inner motivation.
\end{abstract}

Keywords: health education, healthy lifestyle, non-governmental organization, qualitative content analysis, relationship.

\section{Introduction}

Relationship is one of the three natural person's psychological needs (in addition to autonomy and competence), the satisfaction of which ensures the person's development, integrity, good mental and physical health (Ryan, 1995; Deci \& Ryan, 2000; Ryan \& Deci, 2000a, b; Ryan, Patrick, Deci, \& Williams, 2008b; Vansteenkiste \& Ryan, 2013), and develops and shapes health in regard to a person's behavior (Ryan et al., 2008b). Since many of the person's lifelong activities are related to other social actors and are oriented towards the survival of the feeling of belonging to others, the need for relationship is realized through communication and care for others (Deci \& Vansteenkiste, 2004) and 
maintaining meaningful relationships with them (Reis, Scheldon, Gabe, Roscoe, \& Ryan, 2000). Creation of relationship is related to the process of personal development, since only an internal maturity enables a person to constructively relate and communicate with others, and in particular, to negotiate with the self.

The person's relationships with the self and others are arguably the most important relationship in life. One's relationship with oneself is crucial to proper development. Early in development, relationships with others shape the relationship with oneself. There are intrinsic tendencies about the relationship with oneself as well (Morrison, 2004).

As we grow up, the way we are treated by others, and the way those others deal with themselves, serve as important factors influencing how we address ourselves as adults (Master et al., 2017). Having a really good relationship with the self means that, while the person knows that s/he needs other people in many ways, by adulthood her/his relationship with the self becomes crucial in making the most of personal remaining years (Hinde et al., 2005). What it means to have a good relationship with the self is to aim for giving the person important insights into her/his life.

A constructive relationship is a relationship with the self or others characterized by flexibility of role, mutual concern for the self and / or members' (others') needs, as well as other factors (Morrison, 2004). So in a constructive relationship, the people involved are concerned with one another's needs. It's not just self-centered (Master et al., 2017). The relationship the individual has with her/himself is crucial to her/his own wellbeing and also to creating healthy and happy relationships with others (Hinde et al., 2005).

A constructive relationship with the self and others in this research is related to a healthy lifestyle. A healthy lifestyle is a way of living that lowers the risk of being seriously ill or dying early. Health is not only just about avoiding disease. It is also about physical, mental and social wellbeing. When a healthy lifestyle is adopted, a more positive role model is provided to other people in different contexts (World Health Organization, 2003).

The authors, who analyze the intrinsic psychological needs of a person express the position that focusing solely on the need for relationship regardless of a person's autonomy and competence, can produce negative results (Ryan \& Deci, 2000b). Therefore, it is important to balance the satisfaction of all three needs (Sheldon \& Niemiec, 2006). However, analyzing the development of a person as an essential psychological need and a motivator of life as a whole is referred to as a relationship (Ryan \& Deci, 2000b; Ruzek, Hafen, Allen, Gregory, Mikami, \& Pianta, 2016), the quality of which is determined by the satisfaction of the other two psychological needs - autonomy and competence (Deci \& Vansteenkiste, 2004; Ryan \& Deci, 2006).

The development or creation of relationship is actualized by the theory of self-determination, which is referred to as the fundamental theory of relationships (Guardia \& Patrick, 2008). Although the authors of the aforementioned theory agree that a person, being a social being, can feel well by acting alone (Ryan \& Deci, 2000b), but analyzing the satisfaction of one of the most important natural psychological needs and social 
phenomena associated with it emphasizes the importance of personal interaction with others. The authors analyze how communication with different social groups - parents, teachers and peers - determines academic achievements of adolescents, their commitment, and well-being (King, 2015), and what kind of interpersonal attachment styles are developed with the use of the Facebook social network by seeking to satisfy the need for relationship and psychological well-being (Jin, 2016). Other authors (Hofer \& Busch, 2011; Evans, 2015; Ruzek et al., 2016; Cooke, Fielding, \& Louis, 2016) reveal how satisfaction of the need for relationship and other basic psychological needs in different contexts correlates with personal motivation. Meanwhile, the authors of the self-determination theory reveal the indicators illustrating the consequences in regard to eudaimonia, which is a way of life that makes sense for the person's development (Ryan, Huta, \& Deci, 2008a). But the relationship between the individual and her/himself and others in the context of choosing a healthy lifestyle remains an empty field of research: the research studies, which are performed in relation to healthy lifestyle mostly focus on fragmented variables and does not shape the system and models are lacking in this context. Therefore, the research and model presented in this article seek to fill this gap, at least to some extent.

A person's lifestyle is determined by cultural, social, economic and other environmental factors, and is identified as one of the decisive factors in the individual's health (Thirlaway \& Upton, 2009). Therefore, when discussing a healthy lifestyle, it should be seen as a multi-component phenomenon that describes the person's behavior and quality of life, and is related to wellness - a process involving enthusiasm for living and personalized lifestyle that allows her/him to feel the fullness of life (Jankauskas, 2015). Having chosen a healthy lifestyle, a person realizes her / himself in the process of self-management, which is seen as the process of self-creation. It is understood through free choices by deliberately abandoning harmful behaviors in health by pursuing health-promoting and strengthening practices, developing a positive relationship with the environment and the self, expressing identity and taking responsibility for their health and quality of life.

This research follows the position that only by being able to maintain a proper relationship with oneself, can a person engage in constructive relationship with others; while a healthy lifestyle is one of many paths illustrating the process of development and improvement of personality that creates conditions for constructive relationship with oneself and others. The research question of this study was the following: "What kind of multi-component content emerges when the person is creating a constructive relationship with the self and others when s/he chooses a healthy lifestyle?"

The aim of this study was to reveal a prerequisites, context, strategies, interfering factors, outcomes and the core phenomenon emerging from a person's choice of a healthy lifestyle through the relationship with the self and others. 


\section{Methodological approach}

In the presented research two methods - qualitative content analysis (QCA) and grounded theory (GT) were integrated.

Why such kind of methodological integration is possible? QCA and GT share similarities: i) are based on naturalistic inquiry that entails identifying categories and patterns, and involves rigorous coding; ii) these methods have been considered as equivalent approaches to analyze and interpret qualitative data (Priest et al., 2002). Then the GT is treated as a research methodology, and a QCA as a method (Crotty, 2003), GT is considered a theoretical framework and QCA as a research method of textual data analysis (Patton, 2002). These moments are of great importance in the research. The QCA alone, no matter which type, is considered more technique than the methodology (Crotty, 2003).

The particular research is based on symbolic interactionism as it is related to creating relationship with the self and others by choosing a healthy lifestyle what means that the main focus of the research is on creating the interactions. Thus the conceptual direction of GT is based on symbolic interactionism (Priest et al., 2002), where the "meaning is negotiated and understood through interactions with others in social processes" (Starks \& Trinidad, 2007, 1374). The QCA is a method to classify qualitative data into categories of similar meanings (Moretti et al., 2011). The categories represent explicit or inferred communication (Hsieh \& Shannon, 2005).

Thus for QCA here emerged the need to be strengthened by methodology, which has the background in philosophy of symbolic interactionism and which fits the main concept of qualitative data analysis. Then the GT was a proper methodology to choose in order the particular research would have the philosophical basis, methodology and method; and the common approach to data analysis and coding in both - methodology and method - was also the crucial point (Cho \& Lee, 2014). That's why QCA and GT were integrated.

\section{Participants}

The study involved 20 adults who declare healthy lifestyles: 11 women and 9 men. The informant age ranged from 24 to 71 years (average age 43.5 years). The participants' personal experiences in healthy lifestyles ranged from 1 to 43 years (mean 14.05 years). The study sample combined the methods for the selection of the maximum range of cases and snowballing purposive sampling, which are typical for qualitative research (Creswell, 2013). The research sample deliberately included people who were recommended by existing research participants and who met the sampling criteria for this study: i) every research participant must be completed at least two health education courses organized by Non-Governmental Organizations (NGOs), in which they acquired knowledge and applied it in their personal lives, while preserving and strengthening their health; ii) declares at least three components of a healthy lifestyle from several - proper 
diet, physical exercise, proper sleeping pattern, personal hygiene, absence of bad habits or addiction, health education, safe environment, physical fitness, love through social support and healthy relationships, and emotions (Kindig \& Stoddart, 2003); iii) declares that is committed to one of the four harmful habits of the place of change (Chaves et al., 2015) - smoking cessation, healthy diet, physical activity or psychological stress reduction.

The number of informants selected for the survey was determined by the following factors: a) determination of researchers for the details of the research phenomenon (theoretical saturation); b) semi-structured interview as a data collection method, which is enough to interview 20 informants in order to obtain new relevant information (Green \& Thorogood, 2014). Although based on the above factors, the number of participants in the study was conditionally determined before research, but the condition for data saturation in the analysis of interview texts was important by deciding to include new informants into the study.

\section{Data collection}

For data collection the semi-structured interviews were applied.

Interview questions were focused the following three perspectives (Vollstedt, 2015):

- Perspective of meaning (especially referring to the reconstruction of the self-perception): How does the informant present her / himself? What does the person say about her / himself? What is not mentioned? Which orientations (norms, values, sciences, commonplaces etc.) are relevant for the informant?

- Perspective of structure (especially referring to the reconstruction of the world view): Which conditions are shown as important or relevant for the possibilities and the spheres of action of the self? Which ideas, positions, and assumptions give orientation? Which social relations, institutional or social / historical connections are marked as being important for the self?

- Perspective of action: Which activities/interactions with others does the informant describe? Which options are noticed and how are they dealt with? Are the strategies rather active or passive, target-oriented or tentative seeking?

The additional questions according to the interview situation, were asked (Vollstedt \& Rezat, 2019):

- What? (Which phenomenon is described by the research participant?)

- Who? (Which people were involved? Which roles did they embody, or which ones are assigned to them?)

- How? (Which aspects of the phenomenon were dealt with? Which are left out?)

- Where? (What kind of a context was meaningful?)

- Why? (Which justifications were given?)

- Whereby? (Which strategies were used?)

- What for? (Which consequences were anticipated? 
The above presented list of interview questions' directions shows some of the questions that offered rich answers for the answering and interpretation of the data.

The survey data were collected personally in a meeting with the informants in a convenient place to them (in the informant's home environment, in healthy lifestyle training camps organized by NGOs or in the rooms or auditoriums of the Universities, where researchers work). All semi-structured interviews were recorded using a tape recorder, transcribed and analyzed. The average of one interview time was 49 minutes.

\section{Data analysis}

For the data analysis an inductive latent QCA was chosen, when going from specific to general, individual cases are combined into a whole or a general statement. The smallest data analysis unit was chosen as one full sentence. The inductive latent QCA was selected as a type of QCA because it fits the data analysis approach in GT - categories are not selected before the data analysis and emerge from the empirical data (Cho \& Lee, 2014).

The entire process of inductive latent QCA took place at the stages of preparation, organization and delivery, comprising the following data analysis procedures (Elo \&Kyngäs, 2008; Mayring, 2010; Cho \& Lee, 2014): 1) the choice of the meaningful analysis units (using interview transcripts and field notes); 2) open coding; 3) formulating preliminary codes out of data; 4) data coding; 5) revising codes; 6) abstracting; 7) developing subcategories; 8) forming categories from the clusters of subcategories; 9) preparing the conceptual scheme of categories.

In the research the QCA was applied as a key method with using the GT components (prerequisites, context, action/interaction strategies, interfering factors, outcomes, core phenomenon) of the data analysis approach. These components may be used in the final phases of the empirical data analysis in the research (Hsieh \& Shannon, 2005). The coding types / phases from GT were not used in QCA and original concept of QCA data analysis concept was applied in research. Thus, once all the qualitative categories were formed, they were assigned to GT components and the visual model was formed.

\section{Research ethics}

The ethics of qualitative research relates to the autonomy, welfare and rights of the participants in the study (Orb, Eisenhauer \& Wynaden, 2000). As a result, the researchers, taking the responsibility in regard to interviewees, provided all the information that was of interest to them. Each participant in the study was acquainted with the purpose of the study before the beginning of the interview, and verbal consent was received from all participants in the study. During the research, these essential qualitative research ethical principles were fulfilled (Orb et al., 2000):

- respect for personal dignity - the persons involved in the study had the right to self-determination not to take part in the interview and the opportunity to withdraw from the investigation; 
- confidentiality - in accordance with this principle, the interviews provided in the study report do not specify any identification data (name, surname, place of residence) in the interview excerpts which allow research participants to be recognised; all the interview texts were encoded according to the order of the informant participation in the study;

- privacy - the research participants were asked to inform about the demographic information, which is related only to research needs by leaving the right not to answer (no research participant has used this right).

Ethical issues (including plagiarism, informed consent, misconduct, data fabrication and / or falsification, double publication and / or submission, redundancy) have been completely observed by the authors.

\section{Trustworthiness and credibility}

The selection of the most appropriate method of data collection is essential for ensuring the credibility of QCA (Polit \& Beck, 2012). The strategy to ensure trustworthiness of QCA started by choosing the best data collection method to answer the research questions of interest. In most studies where QCA is used, the collected data are unstructured. However, depending on the aim of the study, the collected data may be open and semi-structured (Elo \& Kyngäs, 2008).

From the viewpoint of credibility, self-awareness of the researcher is essential (Schreier, 2012). Pre-interviews helped to determine whether the interview questions were suitable for obtaining rich data that answer the proposed research question. Interview tapes and transcribed text was examined carefully to critically assess the researchers' own actions. For instance, questions were asked such as "Did I manipulate / lead the participant?"; "Did I ask too broad or structured questions?" (Elo et al., 2014). Such evaluation began at the start of the study and was supported by continuous reflection to ensure the trustworthiness of inductive latent QCA.

Subcategories and categories at a time of data analysis were continuously discussed between researchers throughout the study (Morse et al., 2002). Every researcher did the analysis with every interview data autonomously and then subcategories and categories were discussed and finally formed by their consensus.

Thoroughness as a criterion of validity refers to the adequacy of the data and also depends on sound data saturation. Then it is important for researchers to answer the following questions: "Who are the best informants for the study? Are the data well saturated?"

The saturation of the data may indicate the optimal sample size (Guthrie et al., 2004). By definition, saturated data ensure replication in categories, which in turn verifies and ensures comprehension and completeness (Morse et al., 2002). It is common that all the data are first collected and then analyzed later (Elo et al., 2014). However, in this study the data were collected and analyzed at the same time in order to recognize when saturation is achieved (Guthrie et al., 2004); analysis started after first interview by researchers 
autonomously and then the Skype discussions between researchers followed each step of the analysis.

\section{Findings}

The developed scheme of categories illustrates the model for the creation of creating the relationship with the self and others by choosing a healthy lifestyle (Figure 1). It is manifested in two directions (the relationship with the self and the relationship with others) and is based on experiential learning.

Creating the experiential learning-based personal relationship. The participants in the creating of a relationship with the self and others find meaning through thoughts, spiritual practices and being the role model to others. An "agreement" with the self is possible when a person not only publicly declares promoting a healthy lifestyle, but is aware of her / his choice:

A healthy attitude of thought begins - something that nobody sees. You can talk to one another, but ... as much as you can agree with yourself a little further, and then it grows and grows (5 RP).

A religious confession chosen by the individual determines the ways which are used to create and maintain relationship with the inner self and / or God:

Maintaining peace of mind requires meditation or prayer, considering the confession to which a person belongs. This is the search for a relationship with God, with the inner self, who has come from God. These are things that are tightly (inter) linked, and everything needs to be integrated in order to live healthy lives $(8 R P)$. A relationship with others is developed by being a role model of personal change:

This is the role model so that others can follow it by seeing that you are managing stress differently, that you can learn to live your life completely calmly, no matter how serious the life situations or conditions are or could be (16 RP).

The foundation of the relationship with the self and others is the content of experiential learning in which the learning from others and personal experience through listening to yourself becomes meaningful:

When people with experience in those things appear, you "overgrow". As the ocean reefoverflows with molluscs, you overheat, and it seems to you that that this knowledge and that experience is yours (10 RP).

The success of experiential learning is determined by the personal experience already possessed, which leads to the individual's awareness of personal change:

From personal experience, this awareness depends on how you are determined to change something $(5 R P)$. 
The context of creating a person's relationship through a healthy lifestyle. Speaking about personal change, the research participants link this process with transformations of personality traits, character, behaviors, attitudes and thoughts, and faith in what they do:

A man, believing in something, with his/her inner energy, will follow this step with faith, and will begin to do something (12 RP).

Transformation manifests itself through eliminating unacceptable features and characteristics of the person by experiencing every personal act consciously and realizing that the process of personal change is permanent:

$<\ldots>$ Change $<\ldots>$ but you have to feel it, see it, do it, and you have to do it daily $(19 R P)$.

Through self-education is possible the realization of personal goals determined by the free choice:

I want to improve my life. My self-education will help to accomplish my dreams and achieve my goals, because without it, I can only dream (9 RP).

According to informants, a healthy person should be engaged in any activity that suits her / his personal needs:

A healthy person is one who can do what s/he wants when it allows him/her to take physical and mental opportunities (4 RP).

Assumptions for creating a personal relationship. Research participants (1, 2, 3, 7, $11,14,18 \mathrm{RP})$ associate a self-determination with awareness development and learning to live happily. Awareness is planned and developed with the purpose of practicing the particular practices or impulsively, in the face of real life crises. By understanding this, each person has to decide what kind of consciousness development is best for her / him:

When you know this, it remains to deliberately decide whether to reach the level of a certain life, or to meditate daily and to raise awareness, and to accept each event completely with a different view (2TD).

Learning to live happily the research participants describe as a personality's value orientation towards people, when the individual consciously makes a decision to connect personal happiness with the happiness of other people:

How to learn to live happily and to make others happy (17 RP).

Informants understand a healthy lifestyle in all aspects of personality, from the physical to the spiritual:

In a large mechanism, this healthy lifestyle is a small screw. It's like an iceberg, a small tip, and the bottom of the mind is incomprehensible, that's what I'm trying to enter (13 RP).

Initiative is associated with personality-oriented aspects: work with oneself, and personal change:

No one has to make a good or successful life for you, or change you to be a good, successful person, but only you yourself (20 RP). 
Participants expressed their openness to promoting healthy lifestyle training by NGOs: I lacked any action. When I learned that there is a certain group and there are activities. I just tried it. I wanted to try myself (11 RP).

The decision of informants to live healthily emerged by the occurrence of their own children, higher education studies and knowledge accumulated during the search for the meaning of life:

The knowledge about health and illnesses I acquired during studies. It revealed the whole image, in fact, how much the human diseases are really in people's lives. Thus I need to take care of my body (20 RP).

The acquired knowledge gained the direction for further searching of knowledge and encouraged to take care of own health.

Strategies for creating a personal relationship. By creating a personal relationship in choosing the healthy lifestyle different strategies were applied (Figure 1): self-reflection, targeted searches, targeted choices, developing self-awareness, combining different ways of treatment, personal behavior oriented towards health promotion, targeted choice of activities, and being physically active.

Self-reflection is understood consciously by living in different everyday situations. By observing what s/he eats and by analyzing the bodily consequences of diet, a person can assess what products are healthy for her / him:

A person starts to pay attention to his/her diet and the symptoms how s/he feels later. S/he can easily figure out what is healthy for him/her, and what is unhealthy (2RP).

Through self-education for health-oriented habits, the person, according to the informants, must know her/his own body and empower the selffor self-reflection (5 RP). The perception and meaning of one's own motives in various daily situations enables a person to consciously survive everything:

To learn and to be able to survive in any situation. Learn to survive by understanding what you are doing and why you are doing it (6RP).

The targeted searches are focused on new knowledge and experiences (Knowledge is one of the main things a person must desire to absorb in order to take the right path (8RP)), and answering life questions (But the person has to look for answers by her/himself, only then will they be revealed to her / him (2 RP)) .

The targeted choices are meaningful for the participants in the search for a way of life and through self-education. The person has to choose what the s/he will learn (What to learn, of course, s/he chooses (2 RP)); a way of life leading to fullness and health (You have to pick a path. It's more convenient for one to go on the yoga path, for the other - to do sports or for a healthy way (18 RP)); a way of life that makes sense of a permanent learning (I am learning permanently. I'm working with myself (18 RP)).

The strategy of behavioral attitude oriented towards a health-consciousness reveals not only aspects of personal aspirations in promoting healthy lifestyles (body functionality, 
physical and psycho-emotional health, self-awareness), but specific conditions and factors too (hygiene habits, moderation in casual activities, caring for the body, spiritual wellbeing, applying health promotion rules). A healthy lifestyle, according to informants, must be understood in every aspect of the person's thinking and behavior:

A way of life. Doing exercises from the start of the day. It's what you eat. It is everything: what you do, what you say, where you go, how you express it, all these things are a healthy lifestyle (16 RP).

Factors determining the results of creating the personal relationship. The model (Figure 1) highlights factors that determine the results of creating the personal relationship: internal motivation and self-empowerment for personal change, internal motivation for health promotion, making sense of personal knowledgeability within the life reality, making sense of "here and now" in personal lifestyle, recognizing the necessity of medical emergency, harmony with nature, harmony between personality dimensions.

The research participants claimed that reflective observing of the self and close persons' experiences formed their perception that certain things, for example, harmful habits, undermine the quality of life, and the inner sense of "doing something wrong" has helped to make them a decision about personal change:

I have to change my life, refuse something, learn new rules, overestimate my values, beliefs, which were not my beliefs, but are now (3 RP).

Informants, who participated in healthy lifestyle training sessions organized by NGOs, said that the acquired knowledge encouraged their spiritual transformation, while teaching techniques and the educational environment facilitated personal changes if a person was mature and ready for it:

If you deliberately seek personal change, the technique that is taught gives the opportunity to change yourself (5 RP).

Speaking about personal development and self-improvement, the research participants recognized that NGOs created the educational environment in which preconditions for self-empowerment were developed and the start of a healthy lifestyle was established:

This is just the start, the base from which the idea begins and people search for their own paths, for the self-adapted systems that are most suitable for them (17 RP).

Realizing true human nature, a person approaches not only him/herself but also draws closer to nature:

A healthy lifestyle is a return to yourself, to nature, to carefulness. We are returning home. Returning to the self (5 RP).

Outcomes of creating a personal relationship. Outcomes of creating a personal relationship within a healthy lifestyle (Figure 1) are related to transformations that are manifested in different personal dimensions and were described by informants as changes in personal habits and attitudes, quality of life, physical body, health and raised self-confidence. Changes in personal habits interviewees related to abandonment of harmful habits $(3 \mathrm{RP})$ and physical exercise techniques: 


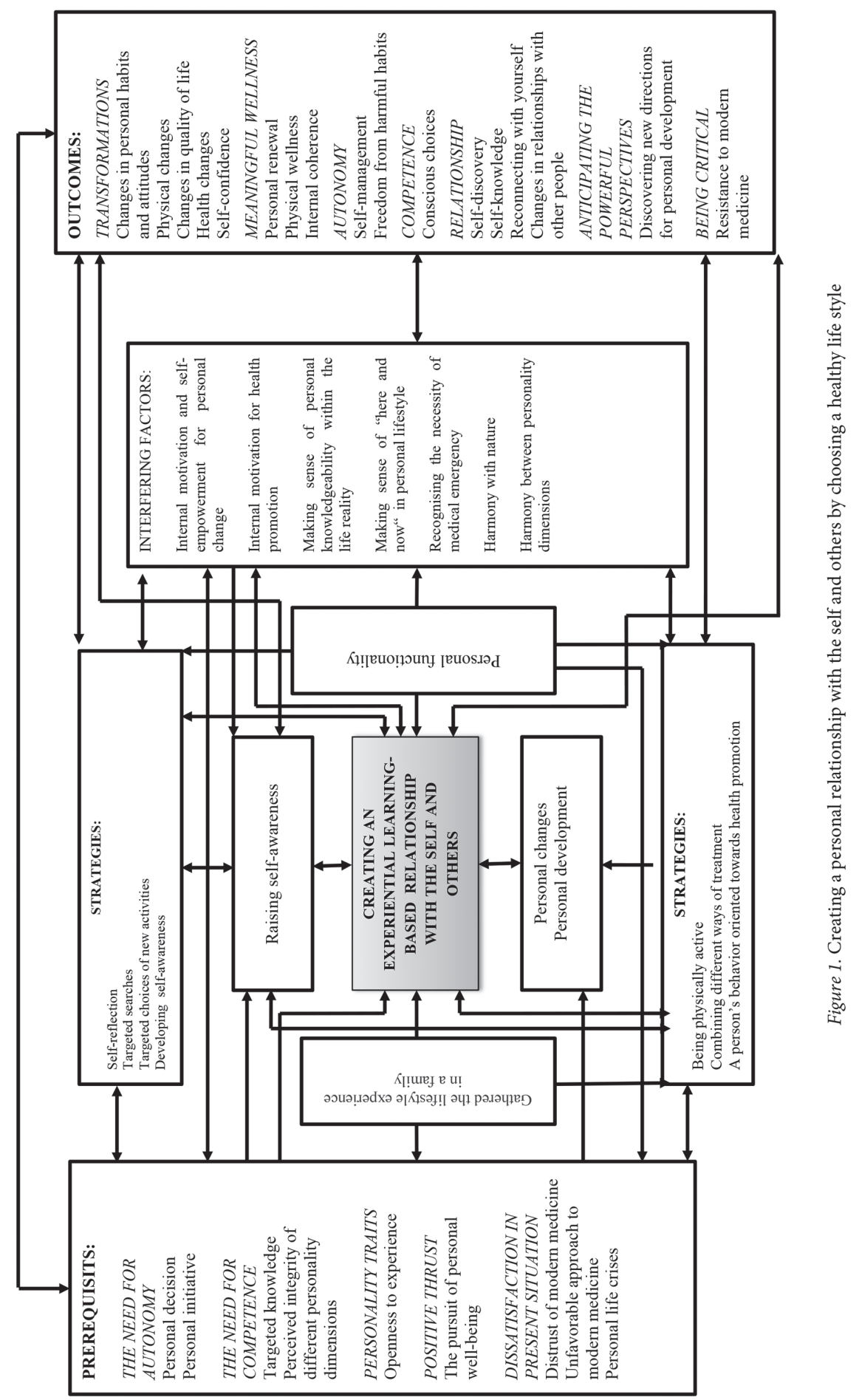


Now I am exercising on a different principle. Previously I understood that muscles need to be developed, now I understand that ligaments are more important ( $8 R P)$.

Informants identified changes in personal attitudes by linking religious beliefs with spiritual values. The spiritual values changed the religious beliefs and attitudes of informants and here could be seen some contradictions:

A healthy lifestyle, when the interest in the spiritual world, spiritual values, and the very onset of my attitude towards religion, to God, arose. And now I consider myself a deeply believing man, but irreligious (3 RP).

Informants mentioned, as a newly discovered and conscious value, building relationships towards helping others:

The most important thing is relationship with people. I think it's most important to me if I can help someone - I'll always help. If I can give something, I will give it. When other people are happy I am happy too (6 RP).

All changes, provided by informants, can be classified as physical (I am almost 50 years old; I do not worry about my heart, there is no arrhythmia, headache, my digestive system is functioning normally and my muscular system is in order, I am not overweight (10 RP)), and psychological (The main change is an internal change. I began to understand more clearly, my mind became more productive, all the depressive feelings disappeared (19 RP)) health.

A healthy lifestyle-based self-confidence in the experience of participants was manifested as the disappearance of emotional constipation:

It's a change of life so I can hug anybody, I can hug a stranger on the street, I am not bashful or cowed anymore (11 RP).

Informants have indicated that exercises that were learned in a healthy lifestyle training improved their mental concentration and helped to relax their physical body:

My body was very tight $<\ldots . .>$ it really relaxed. I became more concentrated $(4 R P)$.

The need for personal relationships in a healthy lifestyle is realized through self-discovery, self-knowledge, restoration of the connection with the self, and changes in relationships with other people (Figure 1).

Informants associate their discovery of the self with different living conditions $(6,17 \mathrm{RP})$, finding the real self in the personal life path that is based on individual needs (3, $8 \mathrm{RP})$, but also becoming aware of the one integral self (19 RP). The discovery of the true self, in the opinion of the informants $(13,15,18 \mathrm{RP})$, is inseparable from spiritual practices, which help to revive the forgotten innate human qualities through get close to the self. Thanks to various self-education and self-centered techniques, by discovering and perceiving oneself as the one, a person implements the main goal of self-education:

The man who discovers her / himself touches deep-seated layers of his/her own; this state is completely natural. S/he discovers that One, and in principle there is nothing to cultivate (10 RP). 
Restoring the relationship with the self for informants means the restoring the inner balance:

Meditation, self-knowledge, allows me to accept myself as I am, because I do not avoid all those bad moods and physical aging (4 RP).

According to the research participants $(9,11,15 \mathrm{RP})$, the changes in the relationships with other people were conditioned by the transformation of personal attitudes, the abandonment of harmful habits, the discovery of spiritual education, meaningful learning of life, and the ability to manage stress due to a healthy lifestyle. Describing changes in relationships with other people, the informants claimed that communication became meaningful:

When I started to meditate, it was somehow going deeper into the self and looking at it, the connection with the external world became totally different. But the desire to be with people and the experience of meaning through being with others is a very good feeling ( $4 R P)$.

For informants the outcome of the relationship with the self and others is the foresight of development prospects what is associated with the discovery of new ways of personal development. The current goals of their lives are oriented towards happiness, which can only be experienced in a meaningful relationship with others:

After a change in attitude, I realized that the key is to be happy and to serve others (18 RP).

\section{Discussion}

The study of creating relationships with the self and others by choosing a healthy lifestyle has depended in part on the recognition that relationships have properties not relevant to interactions or to the behavior of individuals, and may require additional principles of explanation. This has led to an emphasis on relationships as linking the person to the self and other individuals in the context of a healthy lifestyle. In this article, we argue that relationship processes occur in the heads of individuals, with the participants having their own views of the relationship as well as a shared one within the context of choosing a healthy lifestyle. The relationships are both affected by and affect the selfconcepts of the participants, so that the influences of the relationship with the self and others may be critical for understanding the properties and dynamics of relationships.

Based on the qualitative findings and the model (Figure 1) it can be argued that the creation of personal relationships by choosing a healthy lifestyle is influenced by the specific context and assumptions; is carried out with the help of appropriate strategies and focused on the transformation of the personality and quality of life; and is determined by self-empowerment for the personal change, the promotion of inner motivation, and the meaning of the knowledge that exists and other factors. 
Findings revealed that it is meaningful to analyze the context in different sections: as created by a person (growing self-awareness, personal development, personal change) and as conditionally dependent on a person (family experience of a healthy lifestyle, personal functionality). Thus the content of the context created by the person (from our research findings) complements findings of Friedman \& Kern (2014), proving that the inner determination, to be honest, is essential not only to the quality of life but also to longevity.

Findings of the implemented research are consistent with the perception of the theory of self-determination that a person, by choosing the way of life with the focus on personal development, tends to behave prosocially, thus benefiting not only him/herself, but society as well (Ryan et al., 2008a). The prosociality of the informants in particular research was manifested by the example of personal change, i. e. directing the existing experience of a healthy lifestyle and giving personal information to others.

One of the person-dependent (relationship with the self) components of a context is the experience of a healthy lifestyle accumulated in the family, which complements the research findings of the authors of the self-determination theory (Ryan et al., 2008a). Representatives of a self-determination theory state family context is the starting point where autonomy and psychological support are enhanced and relationships then positively affect the mental health of a person, and encourage the individual to strive for personal development and internal satisfaction-oriented goals for life ahead. Our findings support the assumption of Ryan et al. (2008a) that the psychological need for competence in regard to healthy lifestyle is experienced within the family context.

Findings of presented research highlighted that it is meaningful to connect assumptions about the creation of a personal relationship by choosing a healthy lifestyle with the fulfillment of the psychological needs of autonomy and competence, the specific features of personality, the pursuit of prosperity that expresses the positive thrust and the state of dissatisfaction expressed by a person in regard to the existing situation. These results matches the findings of Teixeira, Patrick, \& Mata (2011) who revealed that in the longterm perspective in the context of health-oriented behavioral change and psychological well-being, psychological needs should be linked to personal experiences where competencies mean the developed skills, self-efficacy/trust, positive challenges, and autonomy are seen as consent, will, perceived choice and ownership. In the developed model, personal autonomy, as a prerequisite for creation of personal relationship, is meaningful through personal self-determination and personal initiative. Meanwhile, competence is related to the need for targeted knowledge and the perception of the integrity of the different dimensions of personality, which, unlike the need for targeted knowledge, defines its course only in establishing communication with the self.

When discussing the strategies identified in the model (Figure 1), it should be noted that they are oriented both to the change in the person's behavior related to health promotion and to the personal development process itself. 
The content of the outlined strategies in our model confirms the insight of the representatives of self-determination theory (Ryan et al., 2008a) that the basis of life-oriented personal development is not only the satisfaction of the basic psychological needs of the individual, the pursuit of inner goals and values, but also attention, consciousness, autonomy, valor and voluntary personal behavior. Thus our research findings are complementary to self-determination theory: being in line with the position that a healthy lifestyle is one of the health paths for creating the relationship with the self and others, illustrating the process of personal development, which fosters the person to use different strategies for the health sustainability and its reinforcement. It makes sense to treat this not as the purpose of person's activity, but as a value. Thus our research finding coincides with the insight of Segar (2015) that health should be identified as the reflection of the person's experience and performance that gives her / him meaning and satisfaction in her / his life.

Interfering factors, which influence outcomes of creation of personal relationship in our research are related to personal motivation to a healthy lifestyle and personal change, self-empowerment for personal change, harmony, knowledgeability and meaningfulness of experience. The content of personal motivation (inner motivation for personal change and healthy lifestyle) corresponds to the Deci \& Vansteenkiste (2004) assumptions on inner motivation, named by these authors as behavior; it is oriented to personal growth, and is the basis for personal learning and improvement. Thus, our research findings suggest that after self-empowerment for personal change, the individual becomes less dependent on external motivation resources, and the internal personal or autonomous motivation becomes the inspirational source for the main personal change in regard to a healthy lifestyle. This research finding confirms the assumption of Segar (2015) that external energy sources are effective in initiating a person's behavior change, but in order to preserve new patterns of behavior for a long time, external resources are not enough.

Findings of our research showed that outcomes when a person chooses a healthy lifestyle, such as positive personal transformation, personal development, and meaningful welfare (Figure 1) include components that in the research-based works, which are assigned to self-determination theory (Deci \& Ryan, 2000; Deci \& Vansteenkiste, 2004; Vansteenkiste et al., 2006, 2010) are related to inner purposes of personal activity and life. In our research we highlighted that the individual who chooses a healthy lifestyle as the personal way of development and self-improvement, experiences transformation of personal attitudes, habits, and behavior, but at the same time s/he restores the internal relationship with the self and creates meaningful relationships with others, realizes the psychological needs for autonomy and competence, and discovers directions for personal development.

Limitations. Several limitations when completing the particular research could be reflected: i) Because of theoretical saturation, anticipating the length of the research period was difficult. All the processes within the research were a labor-intensive and 
time-consuming, and the coding and category schemes became quite complex. ii) The most commonly used method in QCA studies is snowballing purposive sampling. This type of sampling is suitable where the researcher is interested in research participants who have the best knowledge concerning the research topic. When implementing such sampling, decisions need to be made about who or what is sampled, what form the sampling should take, and how many people or sites need to be sampled (Creswell, 2013). However, a disadvantage of snowballing purposive sampling is that it is difficult for the reader to judge the trustworthiness of sampling. iii) Research quality is dependent on the individual skills of researchers and more easily influenced by the researchers' personal biases and idiosyncrasies, such as being advocate of a healthy lifestyle or being neutral regarding this attitude. iv) The researcher's presence during the data gathering, which is often unavoidable in qualitative research, could affect the subjects' responses (Anderson, 2010).

Further perspectives of the research. The research has the potential to be developed within specific groups or communities, such as researchers, teachers, etc., but with the focus on particular authentic research focus - creating the relationship with the self and others, and the same particular context - choosing a healthy lifestyle.

\section{Conclusion}

Creating a personal relationship with the self and others within a healthy lifestyle is based on experiential learning and manifests itself in a person's proactivity, awareness and development. Meeting the needs of autonomy and competence predetermine inner personal motivation and is a personality trait. It characterizes personal openness and the pursuit of a personal well-being or dissatisfaction with the current situation, and creates preconditions for creation of personal relationships. Strategies used to create a personal relationship are related to personal development and the targeted choice of the way of personal life and the context of the creation of personal relationships by choosing a healthy lifestyle.

The results of the creation of a personal relationship by choosing a healthy lifestyle are the transformations of the personality and quality of life, which are conditioned by personal change in the person's becoming and the promotion of inner motivation. The transformation of personality determined by choosing a healthy lifestyle is manifested not only through changes in personal attitudes and habits, but also through orientation towards constant personal development. The growing awareness influences the change of personal habits, attitudes and affects the changes in the health preservation and enhancement-based behavior of the individual, and, in essence, leads to changes in a relationship with the self and others. 


\section{References}

Anderson, C. (2010). Presenting and Evaluating Qualitative Research. American Journal of Pharmaceutical Education, 74(8), 141-152. PMCID: PMC2987281.

Chaves, G., Britez, N., Munzinger, J., Uhlmann, L., Gonzalez, G., Oviedo, G., Chaparro, V., Achon, O., Bryckner, Th., Kieser, M., Katus, H. A., \& Mereles, D. (2015). Education to a Healthy Lifestyle Improves Symptoms and Cardiovascular Risk Factors - AsuRiesgo Study. Arquivos Brasileiros de Cardiologia, 104(5), 347-355. doi: 10.5935/abc.20150021.

Cho, J. Y., \& Lee, E.-H. (2014). Reducing Confusion about Grounded Theory and Qualitative Content Analysis: Similarities and Differences. The Qualitative Report, 19(32), 1-10. Retrieved from http://nsuworks.nova.edu/tqr/vol19/iss32/2.

Cooke, A. N., Fielding, K. S., \& Louis, W. R. (2016). Environmentally Active People: the Role of Autonomy, Relatedness, Competence and Self-determined Motivation. Environmental Education Research, 22(5), 631-657. doi: https://doi.org/10.1080/13504622.2015.1054262.

Creswell, J. W. (2013). Qualitative Inquiry and Research Design. Choosing Among Five Approaches (3rd ed.). Los Angeles: Sage.

Crotty, M. (2003). The Foundations of Social Research: Meaning and Perspective in the Research Process (2nd ed.). London, UK: Sage.

Deci, E. L., \& Ryan, R. M. (2000). The "What" and "Why" of Goal Pursuits: Human Needs and Self-Determination of Behaviour. Psychological Inquiry, 11(4), 227-268. doi: https://doi. org/10.1207/S15327965PLI1104_01.

Deci, E. L., \& Vansteenkiste, M. (2004). Self-determination Theory and Basic Need Satisfaction: Understanding Human Development in Positive Psychology. Ricerche di Psicologia, 27(1), 23-40. Retrieved from https://selfdeterminationtheory.org/SDT/documents/2004_ DeciVansteenkiste_SDTandBasicNeedSatisfaction.pdf.

Elo, S., \& Kyngäs, H. (2008). The Qualitative Content Analysis Process. Journal of Advanced Nursing, 62(1), 107-115. doi: 10.1111/j.1365-2648.2007.04569.x.

Elo, S., Käärläinen, M., Kanste, O., Pökki, T., Utriainen, K., \& Kyngäs, H. (2014). Qualitative Content Analysis. SAGE Open, 4 (January-March). doi: 10.1177/2158244014522633.

Evans, P. (2015). Self-Determination Theory: An Approach to Motivation in Music Education. Musicae Scientiae, 19(1), 65-83. doi: http://dx.doi.org/10.1111/j.1365-2648.2007.04569.x.

Friedman, H. S., \& Kern, M. L. (2014). Personality, Well-Being and Health. Annual Review of Psychology, 65, 719-742. doi: 10.1146/annurev-psych-010213-115123.

Green, J., \& Thorogood, N. (2014). Qualitative Methods for Health Research (3rd ed.). Thousand Oaks, CA: Sage. Guthrie, J., Yongvanich, K., \& Ricceri, F. (2004). Using Content Analysis as a Research Method to Inquire into Intellectual Capital Reporting. Journal of Intellectual Capital, 5(2), 282-293. doi: 10.1108/14691930410533704.

Hinde, R., Finkenauer, C., \& Auhagen, A. (2005). Relationships and the Self-Concept. Personal Relationships, 8, 187-204. doi: 10.1111/j.1475-6811.2001.tb00035.x. 
Hofer, J., \& Busch, H. (2011). Satisfying One's Needs for Competence and Relatedness: Consequent Domain-specific Well-being Depends on Strength of Implicit Motives. Personality and Social Psychology Bulletin, 37(9), 1147-1158. doi: 10.1177/0146167211408329.

Hsieh, H-F., \& Shannon, S. E. (2005). Three Approaches to Qualitative Content Analysis. Qualitative Health Research, 15(9), 1277-1288.

Jankauskas, J. P. (2015). Sveikos gyvensenos pagrindai // Basics of Healthy Life Style. Monografija // Monograph. [In Lithuanian language]. Vilnius: Vilniaus universiteto leidykla // Vilnius University Publishing.

Jin, J. H. (2016). Need for Relatedness: a Self-determination Approach to Examining Attachment Styles, Facebook Use, and Psychological Well-being. Asian Journal of Communication, 26(2), 153-173. doi: 10.1080/01292986.2015.1126749.

Kindig, D., \& Stoddart, G. (2003). What is Population Health? American Journal of Public Health, 93, 380-383. doi: 10.2105/ajph.93.3.380.

King, R. B. (2015). Sense of Relatedness Boosts Engagement, Achievement, and Well-being: A Latent Growth Model Study. Contemporary Educational Psychology, 42, 26-38. Retrieved from https://daneshyari.com/article/preview/352546.pdf.

La Guardia, J. G., \& Patrick, H. (2008). Self-Determination Theory as a Fundamental Theory of Close Relationships. Canadian Psychology, 49(3), 201-209. doi: 10.1037/a0012760.

Master, A., Butler, L. P., \& Walton, G. M. (2017). How the Subjective Relationship between the Self, Others, and a Task Drives Interest. In P. A. 0'Keefe, \& J. M. Harackiewicz (Eds.) The Science of Interest (pp. 209-226). Switzerland, Basel: Springer International Publishing AG. doi: 10.1007/978-3-319-55509-6_11.

Mayring, Ph. (2010). Qualitative Inhaltsanalyse. Grundlagen und Techniken. Weinheim: Beltz Verlag.

Moretti, F., van Vliet, L., Bensing, J., Deledda, G., Mazzi, M., Rimondini, M., Zimmermann, C., \& Fletcher, I. (2011). A Standardized Approach to Qualitative Content Analysis of Focus Group Discussions from Different Countries. Patient Education and Counseling, 82(3), 420-428.

Morrison, J. (2004). Understanding Others by Understanding the Self: Neurobiological Models of Empathy and their Relevance to Personality Disorders. The Canadian Child and Adolescent Psychiatry Review, 13(3), 68-73. PMCID: PMC2538737.

Morse, J. M., Barrett, M., Mayan, M., Olson, K., \& Spiers, J. (2002). Verification Strategies for Establishing Reliability and Validity in Qualitative Research. International Journal of Qualitative Methods, 1(2), 1-19. doi: 10.1177/160940690200100202.

Orb, A., Eisenhauer, L., \& Wynaden, D. (2000). Ethics in Qualitative Research. Journal of Nursing Scholarship, 33(1), 93-96. doi: https://doi.org/10.1111/j.1547-5069.2001.00093.x.

Patton, M. Q. (2002). Qualitative Research \& Evaluation Methods (3rd ed.). Thousand Oaks, CA: Sage.

Polit, D. F., \& Beck, C. T. (2012). Nursing Research: Principles and Methods. Philadelphia, PA: Lippincott Williams \& Wilkins. 
Priest, H., Roberts, P., \& Woods, L. (2002). An Overview of Three Different Approaches to the Interpretation of Qualitative Data. Part 1: Theoretical issues. Nurse Researcher, 10(1), 30-42. Reis, H. T., Scheldon, K. M., Gabe, Sh. L., Roscoe, J., \& Ryan, R. M. (2000). Daily Well-Being: The Role of Autonomy, Competence, and Relatedness. Personality and Social Psychology Bulletin, 26(4), 419-435. Retrieved from https://labs.psych.ucsb.edu/gable/shelly/sites/labs.psych.ucsb. edu.gable.shelly/files/pubs/reis_et_al._2000.pdf.

Ruzek, A. E., Hafen, Ch. A., Allen, J. P., Gregory, A., Mikami, A. Y., \& Pianta, R. C. (2016). How Teacher Emotional Support Motivates Students: The Mediating Roles of Perceived Peer Relatedness, Autonomy Support, and Competence. Learning and Instruction, 42, 95-103. doi: 10.1016/j.learninstruc.2016.01.004.

Ryan, R. M. (1995). Psychological Needs and the Facilitation of Integrative Processes. Journal of Personality, 63, 397-427. doi: https://doi.org/10.1111/j.1467-6494.1995.tb00501.x.

Ryan, R. M., \& Deci, E. L. (2000a). Self-Determination Theory and the Facilitation of Intrinsic Motivation, Social Development, and Well-Being. American Psychologist, 55(1), 68-78. Retrieved from https://selfdeterminationtheory.org/SDT/documents/2000_RyanDeci_SDT.pdf.

Ryan, R. M., \& Deci, E. L. (2000b). The Darker and Brighter Sides of Human Existence. Psychological Inquiry, 11(4), 319-338. doi: 10.1207/S15327965PLI1104_03.

Ryan, R. M., \& Deci, E. L. (2006). Self-Regulation and the Problem of Human Autonomy: Does Psychology Need Choice, Self-Determination, and Will? Journal of Personality, 74(6), 1557-1585. doi: 10.1111/j.1467-6494.2006.00420.x.

Ryan, R. M., Huta, V., \& Deci, E. L. (2008a). Living Well: A Self-Determination Theory Perspective on Eudaimonia. Journal of Happiness Studies, 9, 139-170. doi: 10.1007/s10902-006-9023-4.

Ryan, R. M., Patrick, H., Deci, E. L., \& Williams, G. C. (2008b). Facilitating Health Behaviour Change and Its Maintenance: Interventions Based on Self-determination Theory. European Health Psychologist, 10, 2-5. Retrieved from http://selfdeterminationtheory.org/SDT/ documents/2008_RyanPatrickDeciWilliams_EHP.pdf.

Segar, M. (2015). The Right Why: The Surprising Start to Cultivating Sustainable Behavior Change. Generations, 39(1), 15-19.

Sheldon, K., \& Niemiec, C. (2006). It's Not Just the Amount that Counts: Balanced Need Satisfaction Also Affects Well-being. Journal of Personality and Social Psychology, 91, 331-341. doi: 10.1037/0022-3514.91.2.331.

Schreier, M. (2012). Qualitative Content Analysis in Practice. Thousand Oaks, CA: Sage.

Starks, H., \& Trinidad, S. B. (2007). Choose your Method: A Comparison of Phenomenology, Discourse analysis, and Grounded theory. Qualitative Health Research, 17(10), 1372-1380.

Teixeira, P. J., Patrick, H., \& Mata, J. (2011). Why We Eat What We Eat: The Role of Autonomous Motivation in Eating Behaviour Regulation. Nutrition Bulletin, 36(1), 102-107. doi: https:// doi.org/10.1111/j.1467-3010.2010.01876.x.

Thirlaway, K., \& Upton, D. (2009). The Psychology of Lifestyle. Promoting healthy Behaviour. London: Routledge Taylor \& Francis Group. 
Vansteenkiste, M., Lens, W., \& Deci, E. L. (2006). Intrinsic Versus Extrinsic Goal Contents in Self-Determination Theory: Another Look at the Quality of Academic Motivation. Educational Psychologist, 41, 19-31. doi: 10.1207/s15326985ep4101_4.

Vansteenkiste, M., Niemiec, C., \& Soenens, B. (2010). The Development of the Five Mini-Theories of Self-Determination Theory: An Historical Overview, Emerging Trends, and Future Directions. The Decade Ahead: Theoretical Perspectives on Motivation and Achievement Advances in Motivation and Achievement, 16A, 105-165. doi: 10.1108/S0749-7423(2010)000016A007.

Vansteenkiste, M., \& Ryan, R. M. (2013). On Psychological Growth and Vulnerability: Basic Psychological Need Satisfaction and Need Frustration as a Unifying Principle. Journal of Psychoterapy Integration, 23(3), 263-280. doi: 10.1037/a0032359.

Vollstedt, M. (2015). To See the Wood for the Trees: The Development of Theory from Empirical data Using Grounded Theory. In A. Bikner-Ahsbahs, C. Knipping, \& N. Presmeg (Eds.). Doing Qualitative Research: Methodologies and Methods in Mathematics Education. Advances in Mathematics Education Series (pp. 23-48). Heidelberg: Springer. doi: 10.1007/978-94-0179181-6_2.

Vollstedt, M. \& Rezat, S. (2019). An Introduction to Grounded Theory with a Special Focus on Axial Coding and the Coding Paradigm. In G. Kaiser, \& Presmeg, N. (Eds.). Compendium for Early Career Researchers in Mathematics Education. (pp. 81-100). Heidelberg: Springer, Cham. doi: 10.1007/078-3-030-15636-7_4.

World Health Organization. Regional Office for Europe. (1999). Healthy Living: What is a Healthy Lifestyle? Copenhagen: WHO Regional Office for Europe. Retrieved from: https://apps.who. int/iris/handle/10665/108180.

\title{
Santykių su savimi ir kitais kūrimas pasirenkant sveiką gyvenimo būdą
}

\author{
Saulius Vaivada ${ }^{1}$, Vilma Žydžiūnaitè ${ }^{2}$
}

1 Šiaulių universitetas, Edukologijos institutas, P. Višinskio g. 38, 76352 Šiauliai, vaivadas@gmail.com

Šiaulių miesto savivaldybès visuomenès sveikatos biuro visuomenės sveikatos stiprinimo skyrius, Varpo g. 9, 76346

Šiauliai, saulius.vaivada@sveikatos-biuras.lt

2 Vytauto Didžiojo universitetas, Švietimo akademija, Edukologijos tyrimų institutas, Jonavos g. 66, 44191 Kaunas, vilma.zydziunaite@vdu.lt

Klaipėdos valstybinè kolegija, Sveikatos mokslų fakultetas, Slaugos ir socialinės gerovès katedra, K. Donelaičio g. 10, 92143 Klaipèda, v.zydziunaite@ilk.lt

\section{Santrauka}

Tyrimo problema. Žmogus, gebantis palaikyti santykius su savimi, gali užmegzti konstruktyvius santykius / ryšius su kitais, o sveika gyvensena yra vienas iš būdų, atspindinčių 
asmenybės tobulejimą ir sukuriančių sąlygas tokiems ryšiams. Tyrimo metu keltas toks klausimas: „Koks daugiakomponentis turinys iškyla asmeniui, kuriančiam konstruktyvų ryši su savimi ir su kitais, kai pasirenkamas sveikas gyvenimo būdas?“.

Tyrimo tikslas. Atskleisti prielaidas, kontekstą, strategijas, papildomus veiksnius, rezultatus ir „raktinị / esminị“ fenomeną, kurie iškyla asmeniui, kai jis pasirenka sveiką gyvenimo būdą.

Metodologija. Duomenys rinkti pusiau struktūruotu interviu. Tyrime dalyvavo 20 tyrimo dalyvių, baigusių NVO organizuotus sveikos gyvensenos kursus. Galutiniame kokybinių duomenų analizès etape duomenys analizuoti taikant indukcinę latentinę kokybinę turinio analizę, kaip pagrindinị analizès metodą, ir integruojant ši metodą su grindžiamosios teorijos komponentais.

Radiniai. Sukurtas asmeninio ryšio kūrimo pasirenkant sveiką gyvenimo būdą modelis, kuris parodo asmenų, dalyvavusių sveikos gyvensenos mokymuose ir pasirinkusių jị kaip savo gyvenimo tikslą, ryši su savimi ir kitais.

Išvada. Asmeninio ryšio su savimi ir kitais kūrimas pasirenkant sveiką gyvenseną grindžiamas patirtiniu mokymu(si). Asmeninio tobulejjimo rezultatai, pasirenkant sveiką gyvenimo būdą, yra susiję su gyvenimo transformacijų kokybe, kuriai ịtakos turi savęs sutelkimas individualiems pokyčiams, vidinè motyvacija ir prasmès suteikimas turimoms asmeninėms žinioms bei patirtims.

Esminiai žodžiai: sveikatos švietimas, sveikas gyvenimo büdas, nevyriausybinè organizacija, kokybinè turinio analizè, santykis. 